\title{
Use of telemedicine in the management of viral respiratory disease epidemics (SARS, MERS, Influenza, and COVID-19): A review
}

\author{
Sadrieh Hajesmaeel Gohari ${ }^{1(i)}$, Elaheh Shafiei ${ }^{2 *(i)}$, Kambiz Bahaadinbeigy $^{3}$ (i) \\ ${ }^{1} \mathrm{PhD}$ of Health Information Management, Medical Informatics Research Center, Institute for Futures Studies in Health, Kerman University of \\ Medical Sciences, Kerman, Iran \\ ${ }^{2}$ Master of Medical Informatics, Medical Informatics Research Center, Institute for Futures Studies in Health, Kerman University of Medical \\ Sciences, Kerman, Iran \\ ${ }^{3} \mathrm{MD}$, PhD of Medical Informatics, Gastroenterology and Hepatology Research Center, Institute of Basic and Clinical Physiology Sciences, Kerman \\ University of Medical Sciences, Kerman, Iran
}

\begin{tabular}{|c|c|}
\hline Artic & B S T R A C T \\
\hline $\begin{array}{l}\text { Article type: } \\
\text { Review }\end{array}$ & \multirow{2}{*}{$\begin{array}{l}\text { Introduction: The epidemic of viral respiratory diseases in the last } 20 \text { years } \\
\text { has affected many people around the world. In these situations, telemedicine } \\
\text { may reduce unnecessary contacts and the risk of exposure to infection. This } \\
\text { study aimed to review the papers performed to manage viral respiratory } \\
\text { disease epidemics using telemedicine. }\end{array}$} \\
\hline $\begin{array}{l}\text { Article History: } \\
\text { Received: 2021-04-25 }\end{array}$ & \\
\hline $\begin{array}{l}\text { Accepted: 2021-07-11 } \\
\text { Published: 2021-08-08 }\end{array}$ & \multirow{2}{*}{$\begin{array}{l}\text { Material and Methods: The PubMed and Scopus databases were searched } \\
\text { in May } 2020 \text { for this systematic review study. Data were extracted from the } \\
\text { final included papers based on the author, country, type of epidemic, } \\
\text { telemedicine modality, telecommunication method, objective, participants, } \\
\text { clinical outcome, cost, and satisfaction. Descriptive statistics were used to } \\
\text { analyze data. }\end{array}$} \\
\hline $\begin{array}{l}\text { Master of Medical Informatics, } \\
\text { Medical Informatics Research }\end{array}$ & \\
\hline $\begin{array}{l}\text { Center, Institute for Futures Studies } \\
\text { in Health, Kerman University of } \\
\text { Medical Sciences, Kerman, Iran }\end{array}$ & \multirow{3}{*}{$\begin{array}{l}\text { Results: From } 365 \text { retrieved papers, } 18 \text { papers were included. Most of the } \\
\text { papers were done in the US and China (67\%). Half of the papers were done } \\
\text { during the COVID-19 pandemic. Real-time modality was used in } 78 \% \text { of the } \\
\text { papers. The telecommunication method in half of the papers was internet- } \\
\text { based. Patients' management and treatment was the main objective of the } \\
\text { six papers. In } 81 \% \text { of the teleconsultation papers, the consultation was } \\
\text { performed between patients and healthcare providers. The clinical outcome } \\
\text { of all papers showed that telemedicine was successful in the management of } \\
\text { viral respiratory disease epidemics. Cost and satisfaction outcomes were } \\
\text { considered in a few papers. }\end{array}$} \\
\hline afiei.sh@gmail.com & \\
\hline $\begin{array}{l}\text { Keywords: } \\
\text { Telemedicine } \\
\text { Epidemics } \\
\text { Management } \\
\text { SARS }\end{array}$ & \\
\hline $\begin{array}{l}\text { MERS } \\
\text { Influenza } \\
\text { COVID-19 }\end{array}$ & $\begin{array}{l}\text { Conclusion: There is considerable evidence to show that telemedicine is a } \\
\text { useful and convenient method to manage and control viral respiratory } \\
\text { disease epidemics. Therefore, countries should pay special attention to } \\
\text { telemedicine to control the current pandemic and future epidemics and use } \\
\text { it extensively. }\end{array}$ \\
\hline
\end{tabular}

Cite this paper as:

Hajesmaeel Gohari S, Shafiei E, Bahaadinbeigy K. Use of telemedicine in the management of viral respiratory disease epidemics (SARS, MERS, Influenza, and COVID-19): A review. Front Health Inform. 2021; 10: 84. DOI: 10.30699/fhi.v10i1.297

\section{INTRODUCTION}

An epidemic is a sudden increase in the number of particular disease cases in a specific population and area [1]. The epidemic of viral respiratory diseases in the 21 st century has affected many people around the world. The most important respiratory epidemics were SARS (Severe Acute Respiratory Syndrome), Influenza A, MERS (Middle East Respiratory Syndrome), and COVID-19 (Coronavirus Disease 2019). SARS, MERS, and COVID-19 caused by the coronavirus, and Influenza A caused by the influenza virus. If an epidemic affected several continents, it is named a pandemic. Influenza H1N1 and COVID-19 are examples of pandemic diseases.

SARS epidemic was distributed from the Guangdong province of southern China in late 2002 and affected 26 countries with more than 8000 cases and near 800 death [2] . The Influenza A (H1N1) pandemic emerged in Mexico in 2009 and spread across the world fast. This pandemic affected 700 million to 1.4 billion people in 214 countries and at least 18449 deaths worldwide []․ MERS epidemic was first reported in 
Saudi Arabia in 2012. After that, about 2500 cases of MERS were identified in 27 countries and caused 800 people to die [4]. In late 2019, a viral respiratory illness named COVID-19 appeared in Wuhan, China. COVID-19 soon spread throughout China as well as around the world. As of June 19, this pandemic has infected about 8.595.736 people in 213 countries and caused 456,664 deaths worldwide [ [5].

When an epidemic occurs, many activities are taken to control and manage them. One of these activities is the use of telemedicine services. In an epidemic situation, telemedicine may use in different domains such as diagnosis, monitoring, treatment, consultation, and education [6]. Telemedicine could decrease contact between healthcare providers and infected patients and provide healthcare services remotely for healthy people. Therefore unnecessary contact to probably infected health centers could be avoided [7].

During the SARS epidemic, a teleradiology system was used for the diagnosis of SARS cases in China. This web-based interactive system could provide real-time consultation between radiologists with the ability to control and manage DICOM images remotely. With this system, the physicians and radiologists were protected from direct contact with SARS-infected patients []].

In the US, a telephone triage system has been used in response to the H1N1 influenza pandemic. This system provides treatment recommendations about antiviral prescriptions and healthcare center contact by nurses for patients with H1N1 symptoms. This telephonic consultation could reduce face-to-face visits to access healthcare services during the pandemic []].

In the COVID-19 pandemic situation in Switzerland, the latest confirmed information about this new disease was distributed to all healthcare providers by a mobile health platform. This platform was useful for medical staff to reach validated information and utilized them in clinical activities [10].

There are some review studies on telemedicine for fighting against COVID [11-15]. There is not enough evidence about using telemedicine during all respiratory epidemics. Therefore, this study aims to review the papers published in this field and answer the following questions:

In which countries was telemedicine used during viral respiratory disease epidemics?

In which respiratory epidemics telemedicine was used?

Which telemedicine modality was used?

Which telecommunication method was used?

What was the objective of the studies?
Who were the participants in the telemedicine projects?

What was the clinical outcome of the studies?

Was there a cost evaluation in the studies? What was the result of these evaluations?

Was there a satisfaction evaluation in the studies? What was the result of these evaluations?

\section{MATERIAL AND METHODS}

\section{Search strategy}

The Scopus and PubMed databases were searched in May 2020. The search was conducted using the combination of keywords: ((severe acute respiratory syndrome) OR (SARS) OR (middle east respiratory syndrome) OR (MERS) OR (corona) OR (COVID) OR (influenza)) AND ((telemedicine) OR (teleconsultation)). The complete search strategy has been shown in Table 1.

\section{Table 1: Search strategy}

\begin{tabular}{|l|l|}
\hline Database & Search strategy \\
\hline Scopus & ( ( TITLE-ABS-KEY ( "Severe Acute \\
& Respiratory Syndrome") OR TITLE-ABS- \\
& KEY ( SARS ) OR TITLE-ABS-KEY ( "Middle \\
& East Respiratory Syndrome") OR TITLE- \\
& ABS-KEY ( MERS ) OR TITLE-ABS- \\
& KEY ( corona ) OR TITLE-ABS- \\
& KEY ( COVID ) OR TITLE-ABS- \\
& KEY ( influenza ) ) ) AND ( ( TITLE-ABS- \\
& KEY ( telemedicine ) OR TITLE-ABS- \\
& KEY ( teleconsultation ) ) ) AND ( LIMIT- \\
& TO ( LANGUAGE, "English") ) \\
\hline PubMed & ((C((C(Cevere Acute Respiratory \\
& Syndrome) OR SARS) OR Middle East \\
& Respiratory Syndrome) OR MERS) OR \\
& corona) OR COVID) OR influenza) AND \\
& ((telemedicine) OR teleconsultation) \\
& Filters applied: English, Humans \\
\hline
\end{tabular}

\section{Inclusion criteria}

Original papers used telemedicine and tele-education capabilities directly to control and manage SARS, MERS, Influenza, and COVID-19 diseases.

\section{Exclusion criteria}

Letter papers, editorials, review papers, papers without full-text, papers with no sample size, papers on seasonal influenza, papers that were not about epidemic and pandemic, papers that were not done on tele-education and telemedicine services to SARS, MERS, Influenza, and COVID-19 cases directly, and duplicate papers were excluded from the study.

\section{Paper selection}

The search results of two databases were entered 
into EndNote X8 bibliographic software. After removing the duplicate papers, two researchers assessed the title and abstract of the remaining papers independently. Any disagreement between two evaluators was discussed and resolved by consensus, and wherever necessary, the opinion of the third author was asked. In the next step, the full text of the selected papers was screened, and the final list of the included papers was identified.

\section{Data extraction}

Data were extracted from included papers by two evaluators independently based on author, country, type of epidemics, telemedicine modality, telecommunication method, objective, participants, clinical outcome, cost, and satisfaction.

\section{Data analysis}

Data were analyzed using descriptive statistics.

\section{RESULTS}

In total, 365 articles were extracted from PubMed and Scopus databases. After removing duplicate articles, 296 articles reviewed using titles and abstracts. Of these, 39 articles were retrieved for further inspection with full-text (Fig 1).

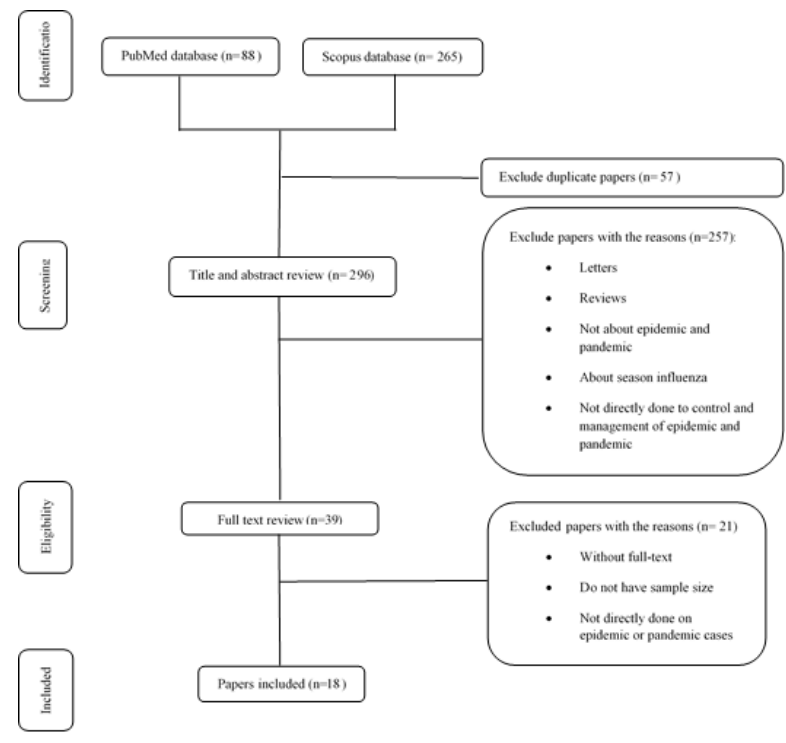

Fig 1: The PRISMA flowchart to find papers

Finally, 18 related papers were included in this study and provided the following results (Table 2).

\section{Country}

Seven papers were performed in the United States (39\%), five papers in China (28\%), two papers in Switzerland (11\%), and the remaining papers were conducted in other countries $(n=4,22 \%)$.

Type of epidemic
Nine papers $(50 \%)$ were in the context of the COVID19 pandemic, seven papers (39\%) were about the influenza epidemics or pandemic, and two papers (11\%) about the SARS epidemic.

\section{Telemedicine modality}

Most papers used real-time telemedicine $(n=14$, $78 \%)$, three papers used store and forward (16.5\%), and one paper used hybrid telemedicine (5.5\%).

\section{Telecommunication method}

Half of the papers used the internet-based method for telecommunication, seven papers used the telephone-based method (39\%), and two papers used both of them to communicate (11\%).

\section{Objective}

The objective of the study in 6 papers $(33 \%)$ was patients' management and treatment, in 5 papers (28\%) was triage of patients, in 2 paper (11\%) was education and in 5 papers (28\%) were other purposes such as prevention, diagnosis, and surveillance.

\section{Participants}

In teleconsultation papers $(n=16)$, most communication $(n=13,81 \%)$ was conducted between patients and health care providers, and three papers (19\%) between physicians and radiologists. In Teleeducation papers $(n=2)$, one paper was conducted for emergency nursing interns' education, and another one was conducted for medical staff education.

\section{Clinical outcome}

All of the studies (100\%) showed that telemedicine to manage epidemic diseases was successful.

\section{Cost}

Three papers $(17 \%)$ analyzed the cost-effectiveness of telemedicine projects used during the epidemics and found that these projects reduced the healthcare system costs.

\section{Satisfaction}

Three papers $(17 \%)$ analyzed the satisfaction of those who used telemedicine during epidemics and found that most of the participants were satisfied.

\section{DISCUSSION}

Results showed telemedicine is a useful and appropriate method to provide and access healthcare services during viral respiratory disease epidemics. The US and China published more papers on telemedicine (with specified eligibility criteria) than the other countries. The Influenza H1N1 and COVID- 
19 pandemics spread rapidly in the US. Currently, the

of COVID-19 []‥

US has the most number of positive cases and deaths

Table 2: Extracted information from included papers

\begin{tabular}{|c|c|c|c|c|c|c|c|c|c|}
\hline 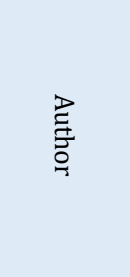 & ○ & 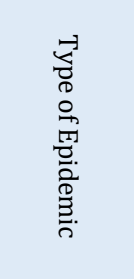 & 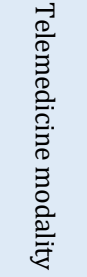 & 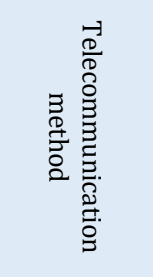 & 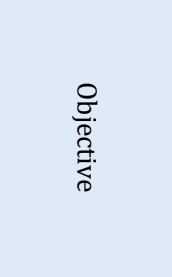 & 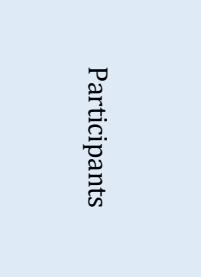 & 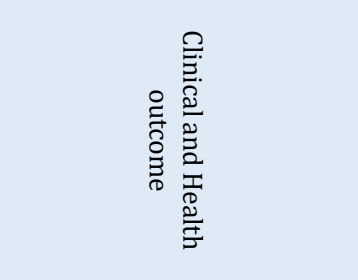 & \begin{tabular}{l} 
ঠ \\
\hdashline
\end{tabular} & 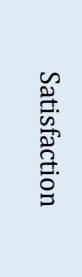 \\
\hline $\begin{array}{l}\text { Blozik, et } \\
\text { al [16] }\end{array}$ & Switzerland & Influenza & $\begin{array}{l}\text { Real- } \\
\text { time }\end{array}$ & Telephone & $\begin{array}{l}\text { Patients' } \\
\text { surveillance }\end{array}$ & $\begin{array}{l}\text { Patients and } \\
\text { physician }\end{array}$ & $\begin{array}{l}\text { This teleconsultation service } \\
\text { could help influenza } \\
\text { surveillance in real-time. }\end{array}$ & ------ & -------- \\
\hline $\begin{array}{l}\text { Borchert, } \\
\text { et al [1]] }\end{array}$ & US & COVID-19 & $\begin{array}{l}\text { Real- } \\
\text { time }\end{array}$ & Telephone & $\begin{array}{l}\text { Patients' } \\
\text { management }\end{array}$ & $\begin{array}{l}\text { Patients and } \\
\text { physician }\end{array}$ & $\begin{array}{l}\text { The use of the urology } \\
\text { teleconsultation triage } \\
\text { provided proper patient } \\
\text { management and reduced } \\
\text { the risk of contact to } \\
\text { coronavirus for patients and } \\
\text { physicians. }\end{array}$ & ------ & -------- \\
\hline $\begin{array}{l}\text { Chang, et } \\
\text { al [1] }]\end{array}$ & Taiwan & SARS & $\begin{array}{l}\text { Real- } \\
\text { time }\end{array}$ & $\begin{array}{l}\text { Video } \\
\text { conference }\end{array}$ & $\begin{array}{l}\text { Patients' } \\
\text { treatment }\end{array}$ & $\begin{array}{l}\text { Patients and } \\
\text { physician or } \\
\text { nurses }\end{array}$ & $\begin{array}{l}\text { The psychosocial status of } \\
\text { the patient was improved } \\
\text { and the risk of affecting by } \\
\text { SARS for healthcare } \\
\text { providers was reduced } \\
\text { using telepsychotherapy } \\
\text { method. }\end{array}$ & $\begin{array}{l}\text { save lots } \\
\text { of costs } \\
\text { from } \\
7000 \$ \\
\text { to } \\
2000 \$\end{array}$ & -------- \\
\hline $\begin{array}{l}\text { Davarpan } \\
\text { ah, et al } \\
{[\underline{19}]}\end{array}$ & Iran & COVID-19 & $\begin{array}{l}\text { Store } \\
\text { and } \\
\text { forwa } \\
\text { rd }\end{array}$ & $\begin{array}{l}\text { WhatsApp, } \\
\text { e-mail }\end{array}$ & $\begin{array}{l}\text { Patients' } \\
\text { triage }\end{array}$ & $\begin{array}{l}\text { local general } \\
\text { radiologist and } \\
\text { expert thoracic } \\
\text { radiologists }\end{array}$ & $\begin{array}{l}\text { This teleconsultation } \\
\text { method was reliable to } \\
\text { triage of COVID-19 cases. }\end{array}$ & ------ & -------- \\
\hline $\begin{array}{l}\text { Eppes, } \\
\text { et al [20] }\end{array}$ & US & $\begin{array}{l}\text { Influenza } \\
\text { H1N1 }\end{array}$ & $\begin{array}{l}\text { Real- } \\
\text { time }\end{array}$ & Telephone & $\begin{array}{l}\text { Patients' } \\
\text { triage }\end{array}$ & $\begin{array}{l}\text { Patients and } \\
\text { physicians or } \\
\text { nurses }\end{array}$ & $\begin{array}{l}\text { This triage system could } \\
\text { minimize in-person contact } \\
\text { and improved health } \\
\text { outcomes. }\end{array}$ & ------ & (------- \\
\hline $\begin{array}{l}\text { Evans, } \\
\text { et al [21] }\end{array}$ & China & COVID-19 & $\begin{array}{l}\text { Real- } \\
\text { time }\end{array}$ & $\begin{array}{l}\text { The } \\
\text { MGIUS-R3 } \\
\text { remote } \\
\text { robotic } \\
\text { ultrasound } \\
\text { system }\end{array}$ & $\begin{array}{l}\text { Diagnosis } \\
\text { and patients' } \\
\text { surveillance }\end{array}$ & $\begin{array}{l}\text { Medical } \\
\text { assistant and } \\
\text { radiologist }\end{array}$ & $\begin{array}{l}\text { This system was user- } \\
\text { friendly and provided } \\
\text { sonographic images with } \\
\text { high resolution. It also } \\
\text { avoided the risk of COVID- } \\
19 \text { exposure for the } \\
\text { physician. }\end{array}$ & ----- & -------- \\
\hline $\begin{array}{l}\text { Gong, } \\
\text { et al [22] }\end{array}$ & China & COVID-19 & $\begin{array}{l}\text { Store } \\
\text { and } \\
\text { forwa } \\
\text { rd }\end{array}$ & $\begin{array}{l}\text { The } \\
\text { platform of } \\
\text { Zoenet } \\
\text { Health } \\
\text { Company } \\
\text { Limited }\end{array}$ & $\begin{array}{l}\text { Prevention } \\
\text { and control }\end{array}$ & $\begin{array}{l}\text { Patients and } \\
\text { physicians }\end{array}$ & $\begin{array}{l}\text { The use of internet hospitals } \\
\text { in china, provided medical } \\
\text { services to help social } \\
\text { distancing and diminish the } \\
\text { chance of hospital infections. }\end{array}$ & ----- & -------- \\
\hline $\begin{array}{l}\text { Harper, } \\
\text { et al [23] }\end{array}$ & US & $\begin{array}{l}\text { Influenza } \\
\text { H1N1 }\end{array}$ & $\begin{array}{l}\text { Real- } \\
\text { time }\end{array}$ & Telephone & $\begin{array}{l}\text { Patients' } \\
\text { management }\end{array}$ & $\begin{array}{l}\text { Patients and } \\
\text { nurses }\end{array}$ & $\begin{array}{l}\text { Self-care advice could be } \\
\text { useful for managing upper } \\
\text { respiratory infection } \\
\text { symptoms. }\end{array}$ & ----- & -------- \\
\hline $\begin{array}{l}\text { Huang, et } \\
\text { al [24] }\end{array}$ & China & COVID-19 & $\begin{array}{l}\text { Hybri } \\
\text { d }\end{array}$ & WeChat & $\begin{array}{l}\text { Patients' } \\
\text { management }\end{array}$ & $\begin{array}{l}\text { Patients and } \\
\text { physicians or } \\
\text { nurses }\end{array}$ & $\begin{array}{l}\text { The use of this model could } \\
\text { improve confirmed patients' } \\
\text { management, monitoring } \\
\text { acute patients, and self-care } \\
\text { of discharged patients. }\end{array}$ & ----- & -------- \\
\hline $\begin{array}{l}\text { Khairat, } \\
\text { et al [도] }\end{array}$ & US & COVID-19 & $\begin{array}{l}\text { Real- } \\
\text { time }\end{array}$ & $\begin{array}{l}\text { Phone call- } \\
\text { video call }\end{array}$ & $\begin{array}{l}\text { Patients' } \\
\text { triage }\end{array}$ & $\begin{array}{l}\text { Patients and } \\
\text { medical } \\
\text { provider }\end{array}$ & $\begin{array}{l}\text { This virtual method could } \\
\text { offer efficient triaging in the } \\
\text { affected countries. }\end{array}$ & ----- & -------- \\
\hline $\begin{array}{l}\text { North, } \\
\text { et al [ㅁ] }\end{array}$ & US & $\begin{array}{l}\text { Influenza } \\
\text { H1N1 }\end{array}$ & $\begin{array}{l}\text { Real- } \\
\text { time }\end{array}$ & Telephone & $\begin{array}{l}\text { Patients' } \\
\text { triage }\end{array}$ & $\begin{array}{l}\text { Patients and } \\
\text { nurses }\end{array}$ & $\begin{array}{l}\text { This telephone triage system } \\
\text { could support the } \\
\text { management of many } \\
\text { medical access demands. }\end{array}$ & ----- & ------- \\
\hline $\begin{array}{l}\text { Perez, } \\
\text { et al [26] }\end{array}$ & Mexico & COVID-19 & $\begin{array}{l}\text { Real- } \\
\text { time }\end{array}$ & Skype & Prevention & $\begin{array}{l}\text { Patients and } \\
\text { physicians }\end{array}$ & $\begin{array}{l}\text { The implementation of web } \\
\text { conferencing software was }\end{array}$ & $\begin{array}{l}\text { Very } \\
\text { little }\end{array}$ & $90 \%$ \\
\hline
\end{tabular}




\begin{tabular}{|c|c|c|c|c|c|c|c|c|c|}
\hline 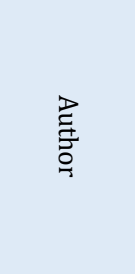 & ڤ & 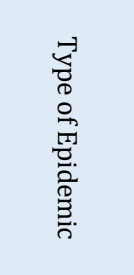 & 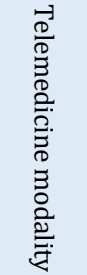 & 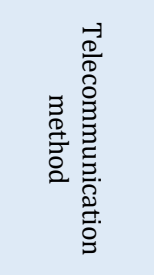 & 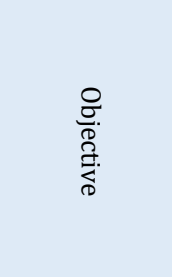 & 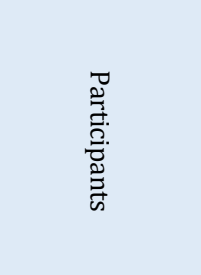 & 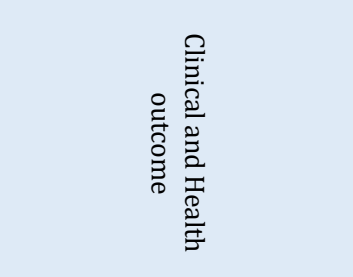 & $\stackrel{\text { }}{\stackrel{n}{n}}$ & 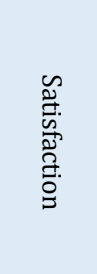 \\
\hline & & & & & & & $\begin{array}{l}\text { easy. This method could also } \\
\text { reduce the exposure of } \\
\text { healthcare providers with } \\
\text { high-risk patients. }\end{array}$ & cost. & \\
\hline $\begin{array}{l}\text { Rothberg, } \\
\text { et al [르] }\end{array}$ & US & Influenza & $\begin{array}{l}\text { Real- } \\
\text { time }\end{array}$ & Telephone & $\begin{array}{l}\text { Patients' } \\
\text { management }\end{array}$ & $\begin{array}{l}\text { Patients and } \\
\text { physicians }\end{array}$ & $\begin{array}{l}\text { Telemedicine could provide } \\
\text { rapid and proper treatment, } \\
\text { and also diminish exposure } \\
\text { to infected cases. }\end{array}$ & ----- & '------- \\
\hline $\begin{array}{l}\text { Rutter, et } \\
\text { al [묘] }\end{array}$ & UK & $\begin{array}{l}\text { Influenza } \\
\text { H1N1 }\end{array}$ & $\begin{array}{l}\text { Real- } \\
\text { time }\end{array}$ & $\begin{array}{l}\text { Telephone, } \\
\text { Internet }\end{array}$ & $\begin{array}{l}\text { Patients' } \\
\text { treatment }\end{array}$ & $\begin{array}{l}\text { Patients and } \\
\text { non-clinically } \\
\text { trained people }\end{array}$ & $\begin{array}{l}\text { This triage system could } \\
\text { provide proper evaluation } \\
\text { and management of patients } \\
\text { by non-clinically trained } \\
\text { people. }\end{array}$ & ------ & -------- \\
\hline $\begin{array}{l}\text { Spaulding } \\
\text {, et al [무] }\end{array}$ & US & $\begin{array}{l}\text { Influenza } \\
\text { H1N1 }\end{array}$ & $\begin{array}{l}\text { Real- } \\
\text { time }\end{array}$ & Telephone & $\begin{array}{l}\text { Patients' } \\
\text { triage }\end{array}$ & $\begin{array}{l}\text { Patients and } \\
\text { nurses }\end{array}$ & $\begin{array}{l}\text { This telephone triage has } \\
\text { the potential to provide an } \\
\text { early evaluation and } \\
\text { intervention to prevent } \\
\text { influenza-associated } \\
\text { morbidity. }\end{array}$ & $\begin{array}{l}\text { From } \\
\$ 876 \\
\text { per visit } \\
\text { to } \$ 12 \\
\text { per call. }\end{array}$ & $91 \%$ \\
\hline $\begin{array}{l}\text { Sun, et al } \\
{[\underline{8}]}\end{array}$ & China & SARS & $\begin{array}{l}\text { Real- } \\
\text { time }\end{array}$ & $\begin{array}{l}\text { Web-based } \\
\text { interactive } \\
\text { tele- } \\
\text { radiology } \\
\text { system }\end{array}$ & Diagnosis & $\begin{array}{l}\text { Physicians and } \\
\text { radiologists }\end{array}$ & $\begin{array}{l}\text { This interactive } \\
\text { teleradiology system was } \\
\text { better than the point-to- } \\
\text { point teleradiology system } \\
\text { in consultation and could } \\
\text { avoid physician exposure to } \\
\text { SARS. }\end{array}$ & -..- & ------- \\
\hline $\begin{array}{l}\text { Zamberg, } \\
\text { et al }[\underline{10}]\end{array}$ & Switzerland & COVID-19 & $\begin{array}{l}\text { Store } \\
\text { and } \\
\text { forwa } \\
\text { rd }\end{array}$ & $\begin{array}{l}\text { Mobile } \\
\text { health } \\
\text { platform }\end{array}$ & Education & Medical staff & $\begin{array}{l}\text { Using this mobile platform } \\
\text { medical staff could access } \\
\text { valid information and use } \\
\text { them in daily procedures. }\end{array}$ & ----- & -------- \\
\hline $\begin{array}{l}\text { Zhou, et } \\
\text { al [임] }\end{array}$ & China & COVID-19 & $\begin{array}{l}\text { Real- } \\
\text { time }\end{array}$ & $\begin{array}{l}\text { Micro- } \\
\text { video }\end{array}$ & Education & $\begin{array}{l}\text { Emergency } \\
\text { nursing interns } \\
\text { and nursing } \\
\text { teaching } \\
\text { supervisor } \\
\text { and clinical } \\
\text { nursing expert }\end{array}$ & $\begin{array}{l}\text { The effect of teaching } \\
\text { emergency nursing practice } \\
\text { using the micro-video } \\
\text { method was similar to } \\
\text { traditional teaching } \\
\text { methods. This method could } \\
\text { minimize the risk of } \\
\text { exposure to COVID-19 for } \\
\text { healthcare providers. }\end{array}$ & ------ & 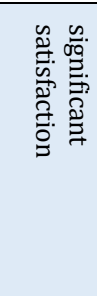 \\
\hline
\end{tabular}

The US is one of the pioneer countries in telemedicine and has even established regulations to use virtual health care services [31]. Therefore, wider use of telemedicine services in the current situation in the US could help reduce the prevalence of COVID-19 [32]. The SARS epidemic and COVID-19 pandemic spread from China. Since China has the largest Med Tech market globally [33], telemedicine services in this country during epidemics were high. In the recent pandemic, remote healthcare services could avoid exposure to COVID-19 infection and control and manage outbreaks rapidly in this country [34].

The COVID-19 pandemic was announced as a public health emergency by the World Health Organization [35]. Many countries are currently affected by the COVID-19 and are using different methods to manage this pandemic. The use of telemedicine is one of these methods that can prevent unnecessary face-to-face contact. For this reason, half of the papers were done during the COVID-19 pandemic. Unfortunately, there was no published paper on the use of telemedicine in the MERS epidemic. Although the MERS epidemic was less prevalent than others, its mortality rate was much higher. Perhaps the use of telemedicine could help to prevent some of these deaths.

Early diagnosis, timely triage, treatment, and monitoring of patients can help to proper management of viral respiratory disease epidemics. For these purposes, the real-time telemedicine modality, as the most used modality in the papers, was proper. The results of a review study in the field of tele pathology showed that store and forward modality was usually used for consultation [36]. This 
shows that due to the non-emergency nature of pathological diagnoses, the store and forward modality as the simplest and the most cost-effective telemedicine method, is used mostly. However, due to the need for timely diagnosis, control, and management, synchronized telemedicine methods are more helpful in the epidemic of viral respiratory diseases. Using internet-based telecommunication methods such as Skype, video calls, and remote interactive systems that were used in half of the papers can provide real-time communication and make sense of face-to-face visits for patients and health care providers in the quarantine situation.

As this study showed, remote consultation of patients with healthcare providers was the main use of telemedicine in the epidemics to manage, treat, and triage patients. Suspected cases could be identified and managed quickly using simple methods such as phone calls. These results were consistent with a similar study that investigate telemedicine applications in coronavirus epidemics [토]. Teleconsultation could prevent patients from unnecessary visiting healthcare centers and reduce the risk of the virus spreading and infecting others, especially medical staff [르].

There was a successful telemedicine experience to manage the epidemic diseases in all papers, and both patients and healthcare providers benefit from this method. Therefore, telemedicine can be used with confidence to manage and control the disease in future epidemics or current pandemic. Depending on the nature of each disease and the difference in the measured clinical outcome, the effect of telemedicine is different. The main clinical outcomes in viral respiratory disease epidemics were timely triage, diagnosis, monitoring, and treatment of patients with reducing exposure to infected cases and transmission of the disease. Therefore telemedicine with providing remote healthcare services could have more positive impacts.

All studies assessed clinical outcomes of the telemedicine system used and showed telemedicine could be used successfully in viral respiratory disease epidemics. However, few studies measured the cost and user satisfaction outcomes of the telemedicine system during these epidemics. Although all of these studies showed that telemedicine has effectively reduced costs and satisfied users, more research is needed to get more definitive results. Cost and user satisfaction are two critical factors in using telemedicine systems widely.

Although many countries, such as developing countries, have been affected by recent epidemics, telemedicine has been used more in developed countries. It seems that despite the advancement in Information and Communication Technology (ICT) and the existence of evidence that telemedicine is useful, developing countries have not yet taken sufficient steps to establish the necessary infrastructure and laws to implement telemedicine [37]. Generally, a study showed that the main barriers to the use and acceptance of telemedicine are technology, opposition to change, cost, and reimbursement issues [효] . Therefore, considering the significant role of telemedicine in controlling viral respiratory epidemics, different countries need to take fundamental steps to address the mentioned barriers to control the current pandemic successfully.

\section{CONCLUSION}

This study showed that telemedicine is a useful and appropriate method to provide healthcare services during viral respiratory disease epidemics and can help to reduce in-person contacts. However, for the widespread use of telemedicine, cost, satisfaction, legal and ethical issues need to be considered.

\section{AUTHOR'S CONTRIBUTION}

All authors contributed to the literature review, design, data collection and analysis, drafting the manuscript, read and approved the final manuscript.

\section{CONFLICTS OF INTEREST}

The authors declare no conflicts of interest regarding the publication of this study.

\section{FINANCIAL DISCLOSURE}

No financial interests related to the material of this manuscript have been declared.

\section{REFERENCES}

1. Centers for Disease Control and Prevention. Introduction to Epidemiology [Internet]. 2012 [cited: 15 Mar 2021]. Available from: https://www.cdc.gov/csels/dsepd/ss1978/lesson1/ section11.html

2. World Health Organization. SARS (Severe Acute Respiratory Syndrome) [Internet]. 2003 [cited: 20 Mar 2021]. Available from: https://www.who.int/ith/diseases/sars/en/
3. World Health Organization. Pandemic (H1N1) 2009 update 112 [Internet]. 2010 [cited: 10 Feb 2021]. Available from: https://www.who.int/emergencies/diseaseoutbreak-news/item/2010_08_06-en

4. World Health Organization. Middle east respiratory syndrome [Internet]. 2015 [cited: 15 Feb 2021; updated: 1 Jun 2021]. Available from: http://www.emro.who.int/health-topics/merscov/mers-outbreaks.html 
5. Worldometer. COVID-19 coronavirus pandemic [Internet]. 2019 [cited: 1 Apr 2021; updated: 9 Aug 2021]. Available from: https://www.worldometers.info/coronavirus/?utm campaign=homeAdUOA?Si

6. Ohannessian R. Telemedicine: Potential applications in epidemic situations. European Research in Telemedicine. 2015; 4(3): 95-8.

7. Smith AC, Thomas E, Snoswell CL, Haydon H, Mehrotra A, Clemensen J, et al. Telehealth for global emergencies: Implications for coronavirus disease 2019 (COVID-19). J Telemed Telecare. 2020; 26(5): 309-13. PMID: 32196391 DOI: 10.1177/1357633X20916567 [ PubMed]

8. Sun J, Zhang J, Zhuang J, Chen X, Yong Y, Tan Y, et al. Developing an interactive teleradiology system for SARS diagnosis. Medical Imaging 2004: PACS and Imaging Informatics. International Society for Optics and Photonics; 2004.

9. North F, Varkey P, Bartel GA, Cox DL, Jensen PL, Stroebel RJ. Can an office practice telephonic response meet the needs of a pandemic? Telemed J E Health. 2010; 16(10): 1012-6. PMID: 21058892 DOI: 10.1089/tmj.2010.0102 [PubMed]

10. Zamberg I, Manzano S, Posfay-Barbe K, Windisch O, Agoritsas T, Schiffer E. A mobile health platform to disseminate validated institutional measurements during the COVID-19 outbreak: Utilization-focused evaluation study. JMIR Public Health Surveill. 2020; 6(2): e18668. PMID: 32250958 DOI: 10.2196/18668 [PubMed]

11. Monaghesh E, Hajizadeh A. The role of telehealth during COVID-19 outbreak: a systematic review based on current evidence. BMC Public Health. 2020; 20(1): 1193. PMID: 32738884 DOI: 10.1186/s12889-02009301-4 [PubMed]

12. Hincapié MA, Gallego JC, Gempeler A, Piñeros JA, Nasner D, Escobar MF. Implementation and usefulness of telemedicine during the COVID-19 pandemic: A scoping review. J Prim Care Community Health. 2020; 11: 2150132720980612. PMID: 33300414 DOI: $10.1177 / 2150132720980612$ [PubMed]

13. Doraiswamy S, Abraham A, Mamtani R, Cheema S. Use of telehealth during the COVID-19 pandemic: Scoping review. J Med Internet Res. 2020; 22(12): e24087. MID: 33147166 DOI: 10.2196/24087 [PubMed]

14. Kichloo A, Albosta M, Dettloff K, Wani F, El-Amir Z, Singh J, et al. Telemedicine, the current COVID-19 pandemic and the future: A narrative review and perspectives moving forward in the USA. Fam Med Community Health. 2020; 8(3): e000530. PMID: 32816942 DOI: $\quad 10.1136 /$ fmch-2020-000530 [PubMed]

15. Gao Y, Liu R, Zhou Q, Wang X, Huang L, Shi Q, et al. Application of telemedicine during the coronavirus disease epidemics: A rapid review and meta-analysis. Ann Transl Med. 2020; 8(10): 626. PMID: 32566563 DOI: $10.21037 / \mathrm{atm}-20-3315$ [PubMed]

16. Blozik E, Grandchamp C, von Overbeck J. Influenza surveillance using data from a telemedicine centre. Int J Public Health. 2012; 57(2): 447-52. PMID: 21318326 DOI: $10.1007 /$ s00038-011-0240-1 [PubMed]

17. Borchert A, Baumgarten L, Dalela D, Jamil M, Budzyn J, Kovacevic N, et al. Managing urology consultations during COVID-19 pandemic: Application of a structured care pathway. Urology. 2020; 141: 7-11. PMID: 32330531 DOI: 10.1016/j.urology.2020.04.059 [PubMed]

18. Chang T, Lee J, Wu S. The telemedicine and teleconsultation system application in clinical medicine. Conf Proc IEEE Eng Med Biol Soc. 2004; 2004: 3392-5. PMID: 17271012 DOI: 10.1109/IEMBS.2004.1403953 [PubMed]

19. Davarpanah AH, Mahdavi A, Sabri A, Langroudi TF, Kahkouee S, Haseli S, et al. Novel screening and triage strategy in Iran during deadly coronavirus disease 2019 (COVID-19) epidemic: Value of humanitarian teleconsultation service. J Am Coll Radiol. 2020; 17(6): 734-8. PMID: 32208138 DOI: 10.1016/j.jacr.2020.03.015 [PubMed]

20. Eppes CS, Garcia PM, Grobman WA. Telephone triage of influenza-like illness during pandemic 2009 H1N1 in an obstetric population. Am J Obstet Gynecol. 2012; 207(1): 3-8. PMID: 22464291 DOI: 10.1016/j.ajog.2012.02.023 [PubMed]

21. Evans KD, Yang Q, Liu Y, Ye R, Peng C. Sonography of the lungs: Diagnosis and surveillance of patients with COVID-19. Journal of Diagnostic Medical Sonography. 2020: 36(4): 370-6.

22. Gong $\mathrm{K}, \mathrm{Xu} \mathrm{Z}$, Cai Z, Chen Y, Wang Z. Internet hospitals help prevent and control the epidemic of COVID-19 in China: Multicenter user profiling study. J Med Internet Res. 2020; 22(4): e18908. PMID: 32250962 DOI: 10.2196/18908 [PubMed]

23. Harper R, Temkin T, Bhargava R. Optimizing the use of telephone nursing advice for upper respiratory infection symptoms. Am J Manag Care. 2015; 21(4): 264-70. PMID: 26014465 [PubMed]

24. Huang S, Xiao Y, Yan L, Deng J, He M, Lu J, et al. Implications for online management: Two cases with COVID-19. Telemed J E Health. 2020; 26(4): 487-94. PMID: 32233973 DOI: 10.1089/tmj.2020.0066 [PubMed]

25. Khairat S, Meng C, Xu Y, Edson B, Gianforcaro R. Interpreting COVID-19 and virtual care trends: Cohort study. JMIR Public Health Surveill. 2020; 6(2): e18811. PMID: 32252023 DOI: 10.2196/18811 [PubMed]

26. Perez-Alba E, Nuzzolo-Shihadeh L, Espinosa-Mora JE, Camacho-Ortiz A. Use of self-administered surveys through QR code and same center telemedicine in a walk-in clinic in the era of COVID-19. J Am Med Inform Assoc. 2020; 27(6): 985-6. PMID: 32282922 DOI: 10.1093/jamia/ocaa054 [PubMed]

27. Rothberg MB, Martinez KA. Influenza management via direct to consumer telemedicine: An observational study. J Gen Intern Med. 2020; 35(10): 3111-3. PMID: 31919730 DOI: $10.1007 / \mathrm{s} 11606-020-05640-5$ [PubMed] 
28. Rutter P, Mytton O, Ellis B, Donaldson L. Access to the NHS by telephone and Internet during an influenza pandemic: An observational study. BMJ Open. 2014; 4(2): e004174. PMID: 24491382 DOI: 10.1136/bmjopen-2013-004174 [PubMed]

29. Spaulding AB, Radi D, Macleod H, Lynfield R, Larson M, Hyduke T, et al. Satisfaction and public health cost of a statewide influenza nurse triage line in response to pandemic H1N1 influenza. PLoS One. 2013; 8(1): e50492. PMID: 23335953 DOI: 10.1371/journal.pone.0050492 [ubMed]

30. Zhou T, Huang S, Cheng J, Xiao Y. The distance teaching practice of combined mode of massive open online course micro-video for interns in emergency department during the COVID-19 epidemic period. Telemed J E Health. 2020; 26(5): 584-8. PMID: 32271650 DOI: $10.1089 /$ tmj.2020.0079 [PubMed]

31. Stapić Z, Vrček N, Hajdin G. Legislative framework for telemedicine. Central European Conference on Information and Intelligent Systems. Varaždin; 2008.

32. Wright JH, Caudill R. Remote treatment delivery in response to the COVID-19 pandemic. Psychother Psychosom. 2020; 89(3): 130-2. PMID: 32213775 DOI: $10.1159 / 000507376$ [PubMed]

33. García-Villarreal E, Bhamra R, Schoenheit M. Critical success factors of medical technology supply chains. Production Planning \& Control. 2019; 30(9): 716-35.
34. Song $X$, Liu $X$, Wang C. The role of telemedicine during the COVID-19 epidemic in China: Experience from Shandong province. Crit Care. 2020; 24(1): 178. PMID: 32345359 DOI: $10.1186 / \mathrm{s} 13054-020-02884-9$ [PubMed]

35. World Health Organization. Rolling updates on coronavirus disease (COVID-19) [Internet]. 2019 [cited:15 Feb 2021]. Available from: https://www.who.int/emergencies/diseases/novelcoronavirus-2019/events-as-they-happen

36. Hajesmaeel-Gohari S, Bahaadinbeigy K, Ahmadian L, Khajouei R, Pournik O. Published papers on telepathology projects. Journal of Health Management \& Informatics. 2015; 2(4):108-19.

37. Keshvardoost S, Bahaadinbeigy K, Fatehi F. Role of telehealth in the management of COVID-19: lessons learned from previous SARS, MERS, and Ebola outbreaks. Telemed J E Health. 2020; 26(7): 850-2. PMID: 32329659 DOI: 10.1089/tmj.2020.0105 [PubMed]

38. Scott Kruse C, Karem P, Shifflett K, Vegi L, Ravi K, Brooks M. Evaluating barriers to adopting telemedicine worldwide: A systematic review. J Telemed Telecare. 2018; 24(1): 4-12. PMID: 29320966 DOI: $10.1177 / 1357633 X 16674087$ [PubMed] 